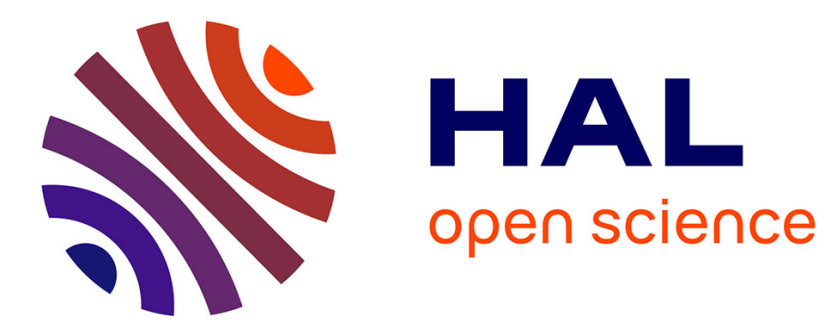

\title{
Economics: Agents, Pilgrims, and Profits Sylvia Chiffoleau
}

\section{To cite this version:}

Sylvia Chiffoleau. Economics: Agents, Pilgrims, and Profits. Tagliacozzo Eric; Toorawa Shawq. The Hajj: Pilgrimage in Islam, Cambrigde University Press, pp.155-174, 2016, 9781107030510. 10.1017/CBO9781139343794.010 . halshs-01419865

\section{HAL Id: halshs-01419865 https://shs.hal.science/halshs-01419865}

Submitted on 1 Jan 2017

HAL is a multi-disciplinary open access archive for the deposit and dissemination of scientific research documents, whether they are published or not. The documents may come from teaching and research institutions in France or abroad, or from public or private research centers.
L'archive ouverte pluridisciplinaire HAL, est destinée au dépôt et à la diffusion de documents scientifiques de niveau recherche, publiés ou non, émanant des établissements d'enseignement et de recherche français ou étrangers, des laboratoires publics ou privés. 


\section{Economics}

\section{Agents, Pilgrims, and Profits}

\section{Sylvia Chiffoleau}

In the nineteenth century, the ancient pilgrimage economy was rocked by technology and administrative rationality. Since the advent of Islam, this economy had been based on the caravan system, the support and subsidies provided by Muslim governments and individuals, and finally, the commercial role of the Hijaz, which had already begun its decline in the eighteenth century. In the Ottoman Empire and Egypt, western pattern of modernity had been widely introduced, albeit selectively, through a series of indigenous reforms (Tanzimât). However, with colonization, modernity penetrated even deeper into the majority of Muslim regions. The pilgrimage, which had hitherto remained a strictly Muslim affair, became a common concern of the colonial powers, which subsequently had to manage it from an administrative and economic perspective. This "European" modernity, however, affected the various economic aspects of the pilgrimage in different ways and according to a varying chronology. With the introduction of steam navigation, which was, in this case, a true revolution, the transportation of pilgrims proved very vulnerable to the assault of European capitalism. The internal economy of Hijaz, on the other hand, was negatively affected by the changes of this period, especially those of a political nature. The disappearance of the financial boon that came with the Ottoman Empire in particular was offset by heavier taxes on the pilgrims. Those driven by faith much more than economic rationality left for Hijaz with very modest means and sometimes in situations of real financial 
insecurity. On arriving in the holy places of Islam, they encountered a level of misery hardly different from their own, which the region's inhabitants sought to relieve by exploiting the pilgrims until the arrival of oil revenues propelled the pilgrimage into a new economic era.

\section{Economic Stakes in the Transportation of Pilgrims}

\section{European Shipping Companies' Control over the Transportation of Pilgrims}

Pilgrimage caravans, which had existed since the Umayyad period, never ceased to grow and develop over the centuries, forming an annual convoy on Middle Eastern routes, which was only interrupted in the event of a major political crisis. During the Ottoman era, caravans had become large-scale events, whose organization was based on a very elaborate economy.1 The two principal caravans departing Cairo and Damascus for Mecca each carried 20,000 to 40,000 pilgrims, a group comprising officials and civil servants accompanied by the amīr al-hajj as well as an imposing military escort. They also transported treasure (surra in Arabic and sürre in Turkish, literally 'purse') comprising gifts and money, which was intended to pacify the Bedouin tribes along the way and subsidize and maintain the holy cities, their elites, and population. This vast

${ }^{1}$ See K. K. Barbir, Ottoman Rule in Damascus, 1708-1758 (Princeton University Press, 1980); S. Faroqhi, Pilgrims and Sultans: The Hajj under the Ottomans (London: I. B. Tauris, 1996); J. Jomier, Le maḥmal et la caravane égyptienne des pèlerins de La Mecque $-X I I I^{e}-X X^{e}$ siècles (Cairo: Imprimerie de l'Institut français d'archéologie orientale, 1953); R. Tresse, Le pèlerinage syrien aux villes saintes de l'Islam (Paris: Imprimerie Chaumette, 1937). 
array of men, animals, and riches was variously financed by a tax levy on the empire's subjects, money and goods from the sultan's personal funds, and income from numerous pious foundations (waqfs). The caravans were also accompanied by tradesmen, who benefitted from the protection of the military escort, as well as many other pilgrims who were engaged in small-scale trade and were thus able to finance all or part of their voyage. In the departure cities, there existed a multitude of trades indispensable for manufacturing the equipment and provisioning the caravans. During the course of the journey, large markets were held in some of the stopovers, which in turn fed the economy of these regions.

This secular organization around the pilgrimage and the intense economic activity that it generated were disrupted by the rapid development of steam navigation in the 1830s. Until the First World War, the Ottoman Empire still continued to send the traditional sürre to Mecca each year, although accompanied by a reduced escort, a mahmal, and a handful of pilgrims. For its part, Egypt retained the privilege of sending the kiswa to Mecca until 1926, but the palanquin, as the symbol of the Egyptian caravan, traveled by boat like its escort from the beginning of the 1880 s. Thus, not only did the show of prestige fade, with its cost yet weighing heavily on the fragile finances of Egypt and the Ottoman Empire, but the marginal economic activity of the caravans virtually disappeared altogether.

For several decades, the use of steam navigation to transport the pilgrims had established a resolutely different economic system. Sailing, particularly in the Indian Ocean, but also to a lesser extent in the Mediterranean, had always contributed to the transportation of pilgrims, strongly interlinking the sacred voyage with the general 
movement of international trade. ${ }^{2}$ However, the development of steam navigation in the nineteenth century substantially increased the flow of people and created a specialized and very competitive market around the pilgrimage. Steam navigation offered a faster, safer, and relatively inexpensive means of transport, allowing a much greater number of pilgrims to undertake the sacred voyage, particularly those from India and Southeast Asia, who until then had depended on the monsoon winds. Despite facilitating the pilgrimage, steam navigation nevertheless opened up the transport industry to European companies and businessmen, an industry that had previously remained the exclusive activity of Muslims. At the same time, by increasing the number of pilgrims and broadening the area of circulation, the flow of cash and wealth between the three continents likewise augmented and intensified, but this occurred in a more diffuse manner than the previous economy that was generated by caravan transport on more limited routes.

In this new market, which witnessed an extraordinary boom with the opening of the Suez Canal (1869), the British navigation companies secured the lion's share from the outset. While the pilgrim flows were henceforth largely superimposed on the colonial trade routes dominated by Great Britain, these companies could mobilise their experience and skills in trade and in the transportation of migrants and plantation workers in order to seize this new opportunity. Founded in 1877, the Bombay and Persia Steam Navigation Co., otherwise known as the Mogul Line, rapidly ascended in this market, eventually running 70 percent of all pilgrimage ships from India at the end of the 1930s. The Blue Funnel Line, whose maritime activities began in the 1850s, also played a significant role in the Indian market as well as in the transport of many

2 M. N. Pearson, Pious Passengers: The Hajj in Earlier Times (New Delhi: Sterling Publishers Private Limited, 1994). 
Maghreb pilgrims on the scheduled shipping lines linking the metropolis to India. At the end of the nineteenth century, the Blue Funnel participated in an Anglo-Dutch consortium involving also two Dutch companies, known as Kongsi Tiga, which had a quasi-monopoly over the transport of pilgrims from Southeast Asia (Malaya, Straits Settlements, and the Dutch East Indies). ${ }^{3}$ In 1887, among the 135 ships transporting pilgrims to Jeddah, 53 were English and 15 were Dutch, and by 1923, British ships had taken charge of 74 percent of pilgrims arriving in Jeddah, while the Dutch transported 20 percent and the other flags shared the remainder. The economic stakes in pilgrim transportation were thus considerable for British and Dutch interests. Despite being somewhat suspicious about the political risks associated with the pilgrimage, the two colonial powers did not obstruct the freedom of movement of the pilgrims under their administration.

On the contrary, France, the third colonial power with many Muslims among its subjects, appeared rather apprehensive about entering this market and initially renounced the idea. In 1877, a report from the Marseilles Chamber of Commerce had deemed it to be unprofitable. The French policy toward the pilgrimage was most uncompromising; out of fear of a "pan-Islamist contamination," it adopted a policy of prohibition, most often justified by reasons of health safety. From 1880 to 1914, the French authorities announced twenty-three prohibitions, thus strongly reducing the pilgrimage market. In the authorized years, though often in violation of the prohibition, Maghreb pilgrims boarded British liners. Although the price of passage was relatively low, the transport conditions were extremely poor. In 1889, the General Government of Algeria issued a decree obliging Algerian pilgrims to board only French boats, which

3 M. B. Miller, "Pilgrims' Progress: The Business of the Hajj," Past \& Present, 191 (2006): 189-228. 
were authorized in advance by a special subcommittee. However, such a monopoly, reinforced after 1928 when the Algerian administration set about organizing the pilgrimage itself, could not apply to the protectorates (Tunisia, Morocco, and Syria), which benefited from the freedom of the flag and instead opted for a concession system following an open call for tender. Thus, strictly controlled by the colonial power, the French market for the transportation of pilgrims never managed to fully develop.

The Ottoman Empire, which had founded a national company in 1856, also participated in the transport of pilgrims, although rather modestly, as did Russia and Austrian Lloyd. Several non-European companies, notably Persian and Indian, or businesses registered in Hong Kong, such as the Nemazee Line, also took part in this operation. The Egyptians, who comprised the third-largest body of pilgrims, were primarily transported by the Khedivial Mail Line, an indigenous company purchased by British interests at the end of the nineteenth century. Despite the proximity of Hijaz, which could have permitted the use of scheduled lines, the Khedivial organized a specialized transport service, because of the obligation for the pilgrim ships to stop on their return from Hijaz at the El-Tor quarantine station, located in the south of the Sinai Peninsula. From the second half of the nineteenth century until the advent of aircraft, the maritime transportation of pilgrims thus constituted a formidable international business with multiple ramifications.

\section{A Competitive and Often Cynical Market}

The majority of shipping companies operating in the pilgrim transport market, especially the British and Dutch, maintained a dense network of native agents, both in Jeddah, the port of disembarkation and embarkation of pilgrims, as well as in the Asian 
regions where the pilgrims were to be recruited. In Hijaz, the management of pilgrims was left to the mutawwifin, guides organized in guilds. These individuals, or more often, their numerous local agents, traversed the concerned areas, including the most remote villages, in order to recruit pilgrims on behalf of the shipping companies, which remunerated them on the basis of the ticket price. The mutawwifin were tasked with providing pilgrims with the necessary papers for their departure and entry into Hijaz; giving them transport tickets including, where applicable, train tickets for local travel; organizing the procedures for traveling to the ports; and so forth. This network of brokers, subject to strong internal competition, developed their own local networks (village chiefs, imams, religious teachers, etc.) to encourage recruitments. They also formed an essential and effective, though not always scrupulous, group of Muslim intermediaries between the pilgrim candidates and the European shipping companies, which maintained a good level of interpersonal relations and ensured the continuity of the economic system.

At the end of the pilgrimage, Jeddah became a place of intense speculation around the sale of return tickets. With the exception of France, which made round-trip tickets compulsory in 1894, the majority of pilgrims set off with a one-way ticket, thus obliging them to buy a return ticket in Hijaz. This was notably the case for the great mass of Malayan and Indian pilgrims. Despite the fact that the fares were theoretically fixed by the vali and that the pilgrims were supposed to have the freedom to choose their own means of transport, the 1880s and 1890s witnessed the establishment of a pool. This pool grouped shipping company agents, community leaders in Hijaz,

\footnotetext{
4 J. Vredenbregt, "The Haddj: Some of Its Features and Functions in Indonesia," Bijdragen tot de Taal-Land en Volkenkunde, 118 (1962): 91-154; Miller, "Pilgrims' Progress."
} 
particularly the Sharif of Mecca, and employees at some of the consulates, who managed to secure a quasi-monopoly on the sale of return tickets, with the consequence that the soaring prices were prejudicial to the pilgrims' interests..$^{5}$ This illegal system of obligation only came to a stop when pilgrims were forced to purchase a round-trip ticket from the outset, which was applied to Dutch subjects in 1922, then incorporated into the 1926 International Sanitary Convention, and extended to Indian pilgrims in the 1930s.

The majority of shipping companies responsible for pilgrim transportation were hardly concerned with their passengers' comfort. They were able to profit from the financial constraints of the pilgrims, who were compensated by their tremendous desire to make the sacred voyage, by imposing harsh, even scandalous transport conditions. The anticipated profits encouraged small companies, often created ad hoc, or even simple adventurers to enter the transportation business. ${ }^{6}$ These companies provided even fewer guarantees than the large enterprises. Cases of overloaded ships, sometimes to incredible proportions, were common, and the chronicle of the voyage to Mecca is interspersed with accidents, fires, and bankruptcies along the way, with companies unable to pay for the coal costs or the Suez Canal tolls.

The political authorities in the countries concerned by the pilgrimage did not ignore the precarious conditions under which the Muslim believers traveled. Attempting to resolve the situation, the French colonial authorities relied on the concession system to enforce restrictive contractual conditions on ship owners and

\footnotetext{
5 W. L. Ochsenwald, Religion, Society and the State in Arabia: The Hijaz under Ottoman Control, 1840-1908 (Columbus: Ohio State University Press, 1984), 101-104.

${ }^{6}$ In 1902, Borel estimated that an average pilgrimage with 45,000 pilgrims earned the shipping companies more than ten million francs: F. Borel, Choléra et peste dans le pèlerinage musulman, 1860-1903 (Paris: Masson et Cie., 1904), 33.
} 
brokers and demand a solid guarantee. The British, who initially refused to impose any limitations on individual pilgrims, instead tried to regulate the transport conditions on the ships, while seeking to protect the competitiveness of their navigation. The 1858 Native Passenger Ships Act, which regulated the transport of "natives" in the Empire, was in principle applicable to the pilgrim ships from 1870 onward. However, for lack of any real progress, the British reached an agreement in 1886 with the company Thomas Cook and Sons to ensure the transport of pilgrims to Hijaz with regard to governmental directives on the sanitary conditions and amenities on board. The solid reputation of the company was supposed to satisfy Muslim leaders, who demanded better treatment for the pilgrims, and prove to the international community that Bombay was no longer the "Sanitary Pariah of the East." 7 However, Cook withdrew from the market in 1893, and two years later, the General Government of India adopted new legislation, the Pilgrim Ships Act, inspired by international legislation. This indeed made it possible to control the abuses in this market. The International Sanitary Conventions, successively adopted from 1894 until 1926, included a meticulous "police regulation of the transportation of pilgrims." Forced to conform to this legislation and under pressure from the colonial powers, which had made pilgrim transport a propaganda issue since the First World War, the majority of shipping companies considerably improved their comfort and safety on board. One the eve of the Second World War, some companies made relatively comfortable and well-equipped steamships available to the pilgrims, with berths for third-class passengers who had hitherto traveled on the ground. These obligations put an end to the most shocking scandals, yet not all of the old vessels were removed from service. The improvements also entailed a loss of profitability in the market.

${ }^{7}$ M. Harrison, Public Health in British India: Anglo-Indian Preventive Medicine, 1859-1914 (Cambridge University Press, 1994), 129. 


\section{Entering the Competition: Nationalist Companies}

In spite of these improvements, the European domination of the pilgrim transportation market was viewed as increasingly alarming with the rise of nationalism. The development of railways at the beginning of the twentieth century offered the Ottoman Empire an opportunity to counter the European quasi-monopoly. In order to reinforce Ottoman control over the turbulent Yemen and relieve pilgrims of their heavy dependence on European shipping companies, the empire decided to construct the Hijaz railway, which would link Damascus to Medina. In viewing the task as having a religious nature, inscribed into the heart of Sultan Abdul Hamid II's pan-Islamic project, there was no question of financing it with foreign capital. The funds were thus raised through gifts following an intense propaganda campaign as well as taxes collected from the inhabitants of the empire and pilgrims. At the official inauguration on September 1, 1908, the Ottoman Empire boasted that the railway was an exclusively Muslim financial enterprise. Its aim of creating competition with European navigation was incidentally achieved: in the first few years of its operation, ${ }^{8}$ approximately 20,000 pilgrims traveled on the railway every year, especially on the return journey, leaving certain maritime entrepreneurs in Jeddah with undercharged boats and facing bankruptcy.

During the interwar period, the overland routes in turn witnessed further development. After the arrival of motor vehicles in the Middle East, a proportion of Persian and Iraqi pilgrims, even Indians, traveled by road from Baghdad to Haifa via Transjordan, or to Beirut via Syria, where they boarded ships to continue their sacred

${ }^{8}$ Damaged by dynamiting during the Arab revolt of 1916-1918 and then split between three sovereignties (Great Britain, France, and Hijaz), the railway was never fully restored for the length of its route. 
voyage. An English company, Mesopotamia Persia Corporation Ltd., was a concessionary in trans-desert transportation along these roads. As the first state in the region to obtain independence, Iraq immediately sought to profit from the transportation of pilgrims. In 1935, Darb Zubayda, the ancient pilgrimage route from Mesopotamia, was reopened and rebuilt in collaboration with Saudi Arabia in order to accommodate motor vehicle traffic. Two native companies, created ad hoc, obtained the concession to transport pilgrims using this new road, thus contributing to the nationalization of Iraqi transport services for the Hajj.

Similarly, in Syria, the economic issue of pilgrim transportation was transformed into a nationalist issue. At the start of the 1930s, the system set up by the French Mandate was disputed on two levels. First, the concession of maritime transport had been granted to a Lebanese Christian company, which collided with the feelings of Muslims. Second, the obligation for pilgrims to use this means of transport forced them to pay a very high price on tickets, with the inclusion of numerous taxes. The financial load was especially unbearable in the years marked by the economic crisis. It quickly transpired that the overland route by motor vehicle was economically more advantageous for pilgrims, thus allowing them to escape the control of the French authorities. In 1935, the same year as the opening of the Baghdad-Medina road, an automobile expedition by Syrian traders made it possible to open, albeit with great difficulty, a road between Damascus and Mecca. However, the initiative, though welcomed by Syrian nationalists, only held a symbolic value in anticipation of independence, since the French authorities upheld their ban on the overland route.

Despite being an even greater distance from Hijaz, the Maghreb countries also sought to travel overland by reviving the ancient trans-Saharan trade routes. Once 
again, this enabled pilgrims to escape from the economic stranglehold and strict control exercised by the colonial administration over maritime transport. Only in 1951 did the first companies for vehicle transport appear, being a commercial network comprising both French companies and indigenous initiatives. Nevertheless, their success quickly spread. In 1955, in Algeria alone, 62 coaches transported 3,000 pilgrims to Suez, a figure greatly exceeding the capacities offered by the official maritime convoy.

A nationalist initiative was again at the origin of the first air service to Hijaz. The Misr Bank, the first Egyptian bank established in 1920 and a symbol of the country's economic revival, obtained the concession from the Egyptian government to organize the Egyptian pilgrimage for a period of twenty-one years. In 1935, it provided pilgrims with two steamboats with all the amenities, and the following year, Misr Airworks, the air transportation sector of the bank, enabled a group of pilgrims to undertake the first plane trip to the sacred territory. After the Second World War, and even more so from the 1960s onward, air transportation developed in the context of decolonization and the creation of nation-states, which supported their national companies at a time when the last European maritime transport companies, shaken by this competition, withdrew from the market, as they no longer yielded the juicy profits of former times. ${ }^{9}$

Figure 10 Four early twentieth-century Hajj functionaries

\section{Hijaz: An Economy Heavily Dependent on Pilgrimage}

Until the 1950s, the Hijaz region subsisted on the pilgrimage as well as aid given by other Muslim countries, and later England, to ensure its longevity. As long as the

${ }^{9}$ Miller, "Pilgrims' Progress." 
caravans still made the sacred journey, although admittedly reduced to a symbolic convoy transported by railway and boat, Hijaz could benefit from the official and substantial aids given by the Ottoman Empire and Egypt, on which it almost entirely depended. However, this donor economy, associated with recurrent attempts at predation toward the pilgrims, was jostled by the political movements that shook the region at the start of the twentieth century: the demise of the Ottoman Empire, followed by the short, but troubled reign of Hussein, and finally the establishment of Saudi power, until the latter profoundly transformed the conditions of the pilgrimage owing to its oil windfall.

\section{A Donor Economy Fed by the Ottoman Treasury and Waqf System}

After seizing power from the Mamluks, the Ottomans endeavored to preserve the system for the exchange of goods, thus allowing the institutions and men of the two holy cities of Islam (haramayn) to continue to be supported. To stress the religious importance of Hijaz, the Ottomans taxed the province very little and accorded it relative autonomy. Moreover, the Ottomans were viewed as being very generous, as were the other Muslim powers and many individuals of wealthy or modest means. The majority of donations and subsidies paid to Hijaz emanated directly from the Ottoman treasury and the sultan's personal funds, but a large part also came from a multitude of pious foundations (waqfs) established throughout the Muslim world. Waqf property, which could comprise buildings, land, or businesses (hammams, shops, etc.), were made inalienable by their owners upon their death, with the usufruct being given to the haramayn either immediately or after the exhaustion of heirs. 
The Ottoman sultans and their families constituted influential waqfs, which were centrally managed in Istanbul. All of the empire's provinces, even the smallest, maintained such waqfs, established by individuals or ruling elites, with the profits flowing to the central fund in Istanbul.10 Other provinces with an autonomous status, such as Algeria in the eighteenth century and Egypt in the nineteenth century, directly managed the revenues and their transfer to Hijaz. In 1830, the city of Algiers counted 1,748 properties set up as waqf al-haramayn, "waqf for the two holy mosques," and the revenue, entrusted to ten notables in the form of gold coins, was sent with the pilgrimage caravan every year or two.11 In Egypt, the waqf al-haramayn established since the Mamluk period were especially numerous and sizable. Between 1880 and 1924, they provided Hijaz with an average annual allowance of 54,350 Egyptian pounds. ${ }^{12}$ Finally, Mecca and Medina possessed numerous waqfs of their own, particularly shops and rental properties intended for the pilgrims, with the income allowing the poor population to be partially supported.

The proportion of the budget allocated to Hijaz by the Ottoman Empire and Egypt was renegotiated each year and was regularly the subject of cost-cutting attempts. At the end of the nineteenth century, Egypt allocated an annual budget of approximately 45,000 Egyptian pounds to the pilgrimage (less than the waqf revenues), about half of which was dedicated to sending grains to Hijaz. On the other hand, Ottoman subsidies primarily took the form of cash transfers. The greatest part of the funds received by the province of Hijaz was devoted to internal security expenditures,

\footnotetext{
10 Faroqhi, Pilgrims and Sultans.

${ }^{11}$ H. Hoexter, Endowments, Rulers, and Community: Waqf Al-Haramayn in Ottoman Algiers (Leiden: Brill, 1998).

12 I. Rif́at Pāshā, Mir’āt al-ḥaramayn (Cairo: Dār al-Kutub al-Mișriyya, 1925), 359.
} 
notably for the police force and army, but also to paying very large, but fluctuating sums of money to pacify the tribes crossed by the flow of pilgrims. The remainder of the sürre was intended to supply the caravans, remunerate their officials, and subsidize the holy cities. This aid flowed primarily to the Sharif of Mecca and his family, then to the elites, particularly the religious elites, and lastly, to the poor, charity organizations, or health and educational institutions for their maintenance. ${ }^{13}$ The money and aid in-kind intended for the Sharif were handed over to him during a great ceremony in Mina at the end of the pilgrimage. Other recipients of the Ottoman sürre and the less significant contributions from Egypt and Algeria were inscribed in registers along with the sum to which each beneficiary was entitled. This was a lifetime privilege, although the sums varied from 1,000 to 2,000 Turkish piastres. ${ }^{14}$ Despite such a codified organization, the distribution of funds was not free from irregularities or even corruption.

\section{British Annuity in Lieu of Ottoman Aid}

The First World War, followed by the fall of the Ottoman Empire, the principal source of Hijaz's aid, brought to an end these traditional forms of subsidies for the holy cities of Islam. The war interrupted the caravan of Damascus carrying the sürre and, of course, it discouraged the pilgrims, quickly threatening the economy of Hijaz. The Egyptian mahmal, however, was sent in 1915 by a British warship, with 20,000 bags of Indian flour to ensure the provision of the province despite the maritime blockade of the Arabian coastline. The beginning of the Arab revolt in June 1916 was accompanied by a massive investment from Great Britain, as much economic as military, in order to lend

13 W. L. Ochsenwald, “Ottoman Subsidies to the Hijaz, 1877-1886," International Journal of Middle East Studies, 6 (1975): 300-307.

14 J. L. Burckhardt, Travels in Arabia, 2 vols (London: Henry Colburn, 1829). 
support to Hussein, the Sharif of Mecca. After the initial payments to back the beginning of the Arab revolt, the British contribution became regular, amounting to approximately $£ 125,000$ per month, with the sum increased to $£ 225,000$ in January 1918 under relentless pressure from Hussein. ${ }^{15}$ These subsidies replaced the traditional modes of aid, thus transferring the dependence of Hijaz from the Ottoman Empire to England, all the while concentrating and privatizing these sums in the hands of the Sharif.

Although reduced after the war, the British subsidies nevertheless continued to flow into the coffers of Hijaz, notably to ensure the security of the pilgrimage, whose defense constituted a moral obligation for the English and a symbol of their domination over the region. However, Hussein's management of the pilgrimage was considered deplorable by all nations concerned. Whereas the pilgrimages at the start of the $1920 \mathrm{~s}$ took place under particularly precarious and dangerous conditions - notably because of attacks on pilgrims, victims of the Bedouin who had not received their usual subsidies the Sharif and his close relations openly indulged in extravagant spending, thus making them reticent to provide their English creditors with an expenditure statement. Exasperated by the situation, the English cut the Sharif's subsidies in February 1920, before renewing them in September of the same year, but at the same level as those transferred to his rival Abdulaziz Ibn Saud, the Emir of Najd, who had profited from British largesse since 1915.16 The Sharif's stubbornness not to fulfil his obligations with regard to the pilgrimage, his opposition to the mandates, and his refusal to negotiate with Ibn Saud eventually contributed to tipping the scales in favor of the latter. In fact,

15 J. Teitelbaum, The Rise and Fall of the Hashimite Kingdom of Arabia (New York University Press, 2001).

16 Teitelbaum, Rise and Fall of the Hashimite Kingdom. 
Ibn Saud had judiciously used the British revenue to secure the allegiance of the tribes, which eventually enabled him to defeat his rival militarily in December 1925.

Although British aid was maintained, it was not sufficient to ensure the ambitions of the new Saudi power. By borrowing from the Indian government, merchants in the Hijaz and Najd, and private British companies, Ibn Saud victoriously succeeded in his fight against the Ikhwan, although not without running up a debt of more than $£ 130,000$ at the beginning of 1931.17 In the years preceding the Second World War, a period marked by the effects of the economic crisis, most of the income in the new Kingdom of Saudi Arabia, which had nevertheless made great efforts to improve the pilgrimage and ensure its safety, came from alms tax (zakāt); from taxes on agriculture, gold, and silver; and from numerous taxes and levies imposed on the pilgrims.

\section{Tax Levying on Pilgrims}

As early as the twelfth century, Ibn Jubayr complained about the taxes levied on pilgrims and the extortion to which they were subjected from the inhabitants of Hijaz. Although the province itself was taxed very little, it benefited from diverse pilgrimage taxes, the number and amount of which greatly fluctuated according to the control exerted by the central authorities - Mamluk and then Ottoman - and the greed of the local elites, especially the Sharif. The revenue base in the province came from customs, with the Sharif and Vali splitting the profits. However, these were naturally insufficient, and if the indispensable subsidies provided by the Ottoman authorities were reduced or

17 J. Kostiner, The Making of Saudi Arabia, 1916-1936: From Chieftaincy to Monarchical State (Oxford University Press, 1993). 
delayed, then the Sharif of Mecca immediately reacted by increasing the taxation on the pilgrims. The most persistent tax in the history of the pilgrimage was the Sharif of Mecca's tax on the hire of camels used to transport pilgrims on the routes between Mecca and 'Arafat, Mecca and Medina, and Yanbu and Medina. It generally represented half of the rental fee, thus forcing the camel brokers to increase it by much more.

The organization of the system of sanitary control for pilgrims in the nineteenth century led to the introduction of sanitary taxes. The pilgrims from the south were subject to a quarantine tax at the Qamaran quarantine station, which varied according to the duration of their stay; those from the north were subjected to a fixed tax at the ElTor quarantine station. The taxes collected in Camaran and El-Tor went respectively to the health boards in Istanbul and Alexandria, which managed these two establishments. After arriving in Jeddah, all pilgrims had to pay an additional sanitary tax, known as the disembarkation tax, which flowed into the coffers of Hijaz province. They also paid a visa fee, and their luggage, whether their personal effects or a few goods intended to supply their modest trade, was subjected to customs duty. To these direct taxes were added indirect contributions through the taxation of foodstuffs consumed on site and charges on the money paid to the agents who organized the pilgrimage.

These taxes soared during the short reign of Hussein. Seeking to increase his income after the Ottoman aid had dried up, the king of Hijaz did not hesitate to tax the pilgrims. In addition to the usual taxes, rising to levels never before seen, the pilgrims had to pay entry and exit fees to the cities of Jeddah, Mecca, and Medina, a tax on tent hire in 'Arafat and another for slaughter in Mina, and finally, an embarkation fee at the end of their costly pilgrimage. In 1922 alone, the British Consul in Jeddah calculated that the Hashemite government collected taxes of approximately 78 rupees or $£ 5$ per 
pilgrim. With 56,000 pilgrims arriving by sea that year, the Sharif would have derived a substantial income amounting to $£ 280,000$.

The condemnation of this racket was unanimous and undoubtedly precipitated the fall of Hussein. When Ibn Saud welcomed the first pilgrimage of his reign in 1926, he assured not only security, but also honesty. One of Ibn Saud's main achievements at the beginning of his reign was not to lower taxes, but to rationalize and codify the tax levying on pilgrims, thus breaking with the arbitrary system that characterized the former period. From 1926 onward, all pilgrims required a passport, which was affixed with a special visa upon their entry to Hijaz, thus allowing the direct taxes to be centralized, although the sanitary and disembarkation taxes were always supplementary. Transportation within the sacred territory, from then on entrusted to automotive companies, was also taxed. However, these taxes paid directly to the government were for the most part removed in 1952 when the state treasury began to receive substantial oil revenues. In 1936, the new customs regulation authorized pilgrims to enter with fifty kilos of provisions and personal effects duty-free, but any belongings subject to customs duty were scrupulously monitored by Ibn Saud's financial advisor and his cohort of agents, who formed the core of the Ministry of Finances. ${ }^{18}$ The perpetuation of the system of direct and indirect tax levies on the pilgrimage allowed the king to ensure the allegiance of the merchant traders living from its revenues, but unlike the period of Hussein's reign, the money collected went, at least partly, toward improving the general conditions and hygiene of the pilgrimage, a fact that was acknowledged by all observers at the time and particularly appreciated by the pilgrims themselves.

18 M. Al-Rasheed, A History of Saudi Arabia (Cambridge University Press, 2010). 


\section{An Economic Ordeal for Pilgrims}

\section{Economic Profile of the Pilgrims}

Although wealthy individuals were never absent from the pilgrimage, the great mass of pilgrims was composed of people from the popular classes - farmers, craftsmen, tradesmen, and later civil servants - the majority being men enough old to invest their entire life's savings into the sacred voyage. For an absence of several weeks or even months in some cases, the cost of the voyage was indeed very high. In the middle of the eighteenth century, the total cost of the voyage by caravan was about 200 piastres, that is to say, more than the price of an average house in Damascus at the time, which was normally some 175 piastres. ${ }^{19}$ While the spread of steam navigation certainly decreased the duration of the voyage, the cost of the pilgrimage continued to represent a considerable financial investment. The economic transformations associated with colonization, and more generally, with the modernization process led to the emergence of new professional categories for making money, which could partly be devoted to the pilgrimage. However, many pilgrims had to resort to their family or loans, or even to the sale of part of their property. Others took regional products to engage in small trade in Jeddah and Mecca, which became commercially animated during the pilgrimage and in return offered a multitude of objects and religious junk for sale. Certain pilgrims departed with only their niyya (pious intention), depending instead on the generosity of their co-religionists along the way. For some, especially the Africans, the pilgrimage was a matter of almost an entire lifetime. They went for many years, and their long journey

\footnotetext{
${ }^{19}$ A. Rafeq, "New Light on the Transportation of the Damascene Pilgrimage during the Ottoman Period," in R. Olson (ed.), Islamic and Middle Eastern Societies (Brattleboro, VT: Amana Books, 1987), 127-136.
} 
was punctuated by stops lasting several years along the road, the time necessary to earn enough money before continuing.

The pilgrimage as an investment was strongly dependent on the general or local economic situation. Economic crises made the number of pilgrims plummet, as was the case in the 1930s. Overseas pilgrims, who had totaled 99,000 in 1928, numbered only 23,000 in 1933 , thus strongly weakening the Hijaz economy and forcing Ibn Saud to maintain the taxation system. In every country and in every region of the Muslim world, the least disruption - drought, bad harvest, grasshopper invasion, and so forth - led to an immediate fall in departures.

Those who did make the journey were subject to different constraints according to their country of origin. In the event of their not returning from the voyage, pilgrims were required to pay their debts and put their affairs in order before departing. Drawing from the Qur'an, which states that the Hajj is a duty only 'for whoever is able to find thereto a way' (Q Âl 'Imrān 3:97), the Dutch authorities imposed the obligation in 1859 for candidate pilgrims to prove that they had the means not only to make the round-trip journey, but also maintain their family for the duration of their absence. ${ }^{20}$ In 1894, the Algerian regulations were aligned along these principles. To obtain the necessary authorization to undertake the pilgrimage, pilgrims had to present the sum required for their journey as well as a guarantee deposit to the colonial authorities. In 1903, Russia in turn required pilgrims to show their possession of sufficient funds to make the round-trip journey. ${ }^{21}$ The British, on the other hand, always refused to impose

${ }^{20}$ W. R. Roff, "Sanitation and Security. The Imperial Powers and the Nineteenth Century Hajj,” Arabian Studies 6 (1982): 143-160.

${ }^{21}$ P. Brower, "Russian Roads to Mecca: Religious Tolerance and Muslim Pilgrimage in the Russian Empire," Slavic Review, 55 (1996): 567-584. 
any conditions on resources, fearing that the Muslims would perceive it as a hindrance to their religious freedom. Thus, depending on the constraints imposed by the colonial powers, the pilgrims arrived in Hijaz with more or less money. Their financial situation incidentally determined the stereotypical perception that the inhabitants of Hijaz had of them. Dutch subjects and Malayans, who tended to remain in the region for a lengthy period of time, were regarded as "good pilgrims" and considered “docile." The Maghreb pilgrims were perceived as miserly, undoubtedly because they stayed in the area for the least amount of time on account of the strict control of the French authorities. Finally, the Indians and, to a lesser extent, the Persians and Russians, often being penniless, were regarded as "bad pilgrims." It is certainly true that once in Hijaz, where the pilgrimage industry was an essential resource for its inhabitants, the pilgrims had to continuously put their hands in their pockets.

\section{A Costly Enterprise}

In addition to the taxes flowing into the province's treasury, or more often, into the Sharif's hands, the pilgrimage activities generated income for a great number of inhabitants in Hijaz, who in a few weeks could earn enough money to subsist for the rest of the year. The main pilgrim services were managed by organizations whose members had paid for the right to exercise these functions, which were often hereditary. The primary organization was that of the guides (muțawwif, pl. muțawwifin) who were allocated different Muslim territories: a particular country or province was thus managed by a certain number of mutawwifs, who in theory were familiar with its language and customs. These Meccan guides supervised the entire stay of the pilgrims: they were indispensable to the travelers who were all ignorant of the country, and they 
played a vital role in helping them perform the religious rituals, notably the numerous prayers, without committing a faux pas. They were paid a sum of money akin to a salary (amāna, literally “objects of trust” ), but they also received plenty of baksheesh to facilitate the procedures. The principal guides had agents (wakīl) in Jeddah, who welcomed the pilgrims on their arrival at the port, dealt with the entry formalities, accommodated them, and then organized their departure by caravan to Mecca. The Meccan mutawwifs then took charge and accompanied their group of pilgrims for the entire duration of the pilgrimage, managing all of the material and spiritual aspects as well as guiding them in their choices and purchases. Medina likewise had its own guides (muzawwir) who assisted the pilgrims during their visit to the city sheltering the tomb of the Prophet. The chain of pilgrimage activities was thus tightly controlled, with the relevant agents (landlords, baggage porters, zemzemî, tent or camel renters, etc.) being remunerated either directly by the pilgrim or through the intermediary of the mutawwif.

The prices for these services, in theory fixed by the vali, were in reality highly variable according to the economic needs of the province, the arbitrariness of its leaders, or the shrewdness of its agents. The consuls in Jeddah strove to follow and bring order to this chaos as a way of updating their supervisory authorities on the situation so that the latter could calculate the approximate amount necessary to undertake the pilgrimage. After the 1908 revolution, the Young Turks tried to lower the prices, especially the remuneration of the mutawwifs, an attempt that was resumed in 1917 with Sharif Hussein, without any more success for lack of a real effort to control the situation. Once again, Ibn Saud managed to put an end to the most blatant abuses, although without succeeding in completely eradicating the exploitation of pilgrims. 
From 1926, an official rate was set each year for all of the proceedings conducted within the framework of the pilgrimage and then distributed across Muslim nations. It was thus possible to determine with a certain degree of precision the sum required for the pilgrimage and inform pilgrims so as to restrict the departures to those who possessed this sum, even if many continued to ignore it. However, after the Second World War, the Kingdom of Saudi Arabia held different nations responsible for respecting these "fixed pilgrim costs.”

The pilgrims were not only confronted with high prices, but also with the constraints of foreign exchange. Under the Ottoman Empire, the Turkish currency was in theory the only legal currency, but in practice, all existing currencies circulated in Hijaz. In the absence of banks, the currencies carried by the pilgrims were changed at a multitude of money changers at highly variable rates. The Indian rupee was the most stable currency, whereas the majority of other currencies, particularly the franc, were exchanged below the normal rate, which put further strain on the pilgrims' budget. These foreign currencies were then used to purchase the imports necessary for the province, especially during the pilgrimage. The obligation imposed by Sharif Hussein and later Ibn Saud to use only gold currency (gold pound sterling) in Hijaz, despite its instability, caused a particular difficulty for Algerian pilgrims. Indeed, as they did not have the right to export gold, France had to set up a complex system to circumvent the unfavorable exchange rate of the franc. From 1929, a French bank opened a branch in Hijaz at the time of the pilgrimage every year in order to reimburse pilgrims the gold exchange value of their checks issued in North Africa, with a credit line being granted by the French government. At the time, even for France, there was no longer any question

22 Vredenbregt, "The Haddj: Some of Its Features.” 
of obstructing Muslims' religious observance. Nevertheless, all of the colonial powers still deplored the financial evasion that the pilgrimage posed to their economies.

\section{Destitute Pilgrims during the Pilgrimage}

Under the pressure of taxes, high prices, and prohibitive food costs, improvident or extravagant pilgrims found themselves without any money left at the end of the pilgrimage and sometimes unable to return home. The impetus of faith that drove pilgrims to the sacred territory was hardly encumbered by economic considerations. The Indians, who were not subjected to any conditions on resources, were the most numerous among these destitute. Each year, approximately one-quarter of the Indian quota was declared destitute at the stopover in Kamaran, where they were exempted from paying quarantine taxes. The Africans, arriving on foot from their remote region, sometimes had to live for several years in Hijaz under miserable conditions before being able to set off again. Finally, the restrictive French policy forced many Maghrebians and later Syrians to make the voyage in "clandestine," that is to say, in violation of the prohibition or outside of the official convoys. Departing without the obligatory controls and often without enough money, they then became blocked in Hijaz.

Once the pilgrimage was over, these destitute individuals crowded the streets of Jeddah while living off charity. They were vulnerable to be victims of the slave trade, especially the Africans, and they suffered a very high mortality rate. These pilgrims thus posed a constant problem, as much for the Ottoman authorities followed by the Sharif and Ibn Saud, who held the colonial powers responsible for them, as for the latter, who had a moral obligation to come to the assistance of these poor, which turned out to be a 
huge financial burden. The French Consulate, which did not have the funds for repatriations, had to improvise each year by drawing from its treasury or cooperating with the shipping companies, which in return accepted an overload in violation of the legislation. The British Consulate resorted to the same expedients, but it also benefited from the assistance of the Anglo-Indian government and funds collected for this purpose by Islamic associations, in particular the Jubilee Indian Pilgrim Fund Relief created in 1897 . Already reduced by the increasingly common obligation to purchase a round-trip ticket, the problem was resolved once and for all with the Saudi residence regulations in 1952.

From the 1930s, ever more demanding and sophisticated Saudi regulations were added to the international sanitary regulations and colonial legislations to help regulate the pilgrimage, especially from an economic perspective. Until the 1950s, however, certain issues still endured, and the complaints, regarding embezzlements in particular, were always numerous. Even though today they have not completely disappeared, after this period, two major events profoundly altered the conditions of the pilgrimage. First, the independence of Muslim countries removed the mediation of colonial powers, thus returning the Hajj to a strictly Muslim affair. Second, the oil revenues allowed the kingdom to break its quasi-exclusive dependence on the pilgrimage, but even more so, to spend colossal sums of money on improving its conditions. Since then, the pilgrimage is no longer perceived as an exploitable resource for the country, but rather as a religious event to manage as best as possible.

\section{Bibliography}

K. K. Barbir, Ottoman Rule in Damascus, 1708-1758 (Princeton University Press, 1980). 
F. Borel, Choléra et peste dans le pèlerinage musulman, 1860-1903 (Paris: Masson et $C^{\mathrm{ie}}$, 1904).

P. Brower, "Russian Roads to Mecca: Religious Tolerance and Muslim Pilgrimage in the Russian Empire", Slavic Review 55/3 (1996), 567-584.

J. L. Burckhardt, Travels in Arabia, 2 vol. (London: Henry Colburn, 1829).

S. Faroqhi, Pilgrims and Sultans. The Hajj under the Ottomans (London: IB Tauris, 1996).

M. Harrison, Public Health in British India: Anglo-Indian preventive medicine, 1859-1914 (Cambridge University Press, 1994).

M. Hoexter, Endowments, Rulers, and Community: Waqf Al-Haramayn in Ottoman Algiers (Brill, 1998).

J. Jomier, Le Mahmal et la caravane égyptienne des pèlerins de La Mecque -XIII ${ }^{e}-X X^{e}$ siècles (Cairo: Imprimerie de I'IFAO, 1953).

J. Kostiner, The Making of Saudi Arabia, 1916-1936. From Chieftaincy to Monarchical State (Oxford University Press, 1993).

M. B. Miller, “Pilgrims' Progress: The Business of the Hajj”, Past \& Present, 191 (2006), 189-228.

W. L. Ochsenwald, "Ottoman Subsidies to the Hijaz, 1877-1886", International Journal of Middle East Studies, 6 (1975), 300-307.

W.L. Ochsenwald, Religion, Society and the State in Arabia. The Hijaz under Ottoman Control, 18401908 (Ohio State University Press, 1984).

M. N. Pearson, Pious Passengers. The Hajj in Earlier Times (New Delhi: Sterling Publishers Private Limited, 1994).

M. Al-Racheed, A History of Saudi Arabia (Cambridge University Press, 2010).

A. Rafeq, "New light on the transportation of the Damascene Pilgrimage during the Ottoman period" in R. Olson (ed), Islamic and Middle Eastern Societies (Amana Books 1987), 127-136.

I. Rifa'at pacha, Mirât al-haramayn (Cairo: Dar al-Kutub al-Masriyya, 1925).

W. R. Roff, "Sanitation and Security. The Imperial Powers and the Nineteenth Century Hajj", Arabian Studies 6 (1982), 143-160.

J. Teitelbaum, The Rise and Fall of the Hashimite Kingdom of Arabia (New York University Press, 2001).

R. Tresse, Le pèlerinage syrien aux villes saintes de I'Islam (Paris: Imprimerie Chaumette, 1937).

J. Vredenbregt, "The Haddj. Some of its features and functions in Indonesia", Bijdragen tot de TaalLand en Volkenkunde, 118 (1962), 91-154. 